\title{
Sea Prayer: An Illustrated Literary Narration on the Afflictions of Refugees
}

\author{
Amal Babu \\ Research Scholar \\ Pt. Ravishankar Shukla University \\ Raipur, Chhattisgarh, India \\ amalbabu2710@gmail.com
}

\begin{abstract}
Illustrated fiction is one of the narrative media that came into the arena of literature during the $18^{\text {th }}$ century because of the technological advancements that occurred during this period. Illustrated editions of literary creations became more popular during the late $18^{\text {th }}$ century until the last decades of the $19^{\text {th }}$ century. During this period, an illustrated edition of fictional works was in higher demand than the prose editions. However, the emergence of various adaptations of literary creations, such as films and graphical representation that came into command at the end of the $19^{\text {th }}$ century and $20^{\text {th }}$ century replaced the popularity of illustrated fiction. Khaled Hosseini, one of the beloved writers of the $21^{\text {st }}$ century has documented the sufferings of Afghan society in his three novels; The Kite Runner (2003), A Thousand Splendid Suns (2007), and And the Mountains Echoed (2013). His works explore the sufferings of common people under the dark shadows of war and violence and spread the rays of peace and humanity. His latest work, Sea Prayer, published on 18 September 2018, Illustrated by Dan Williams, is also deals with the perennial problems faced by the human race in the modern world; war, violence, and refugee life. Written in the form of a letter from a father to son, on the eve of their journey to find their new home, the work describes the
\end{abstract}


traumatic condition of the Syrian refugees and the glory of pre-war Syria. Thus, Hosseini urges the readers to reflect on the dilemmata faced by the Syrian society during the period of war and to hold their hands together to bring peace in Syria and all over the world. Keywords: Popular Literary Forms, Illustrated Fiction, Khaled Hosseini, Sea Prayer, Syria, War and Violence, Peace and Humanity.

The history of book illustration came into existence in some form along with the advent of the written word. The tradition of book illustration originated in the western literature during the $15^{\text {th }}$ century in the form of block books along with its prose edition. The book illustration found a drastic development in the late $18^{\text {th }}$ century due to the enormous technical progress that transpired during the period. The presence of illustrated editions of literary creations in the world of adult fiction commenced along with the origin of novels in the $18^{\text {th }}$ century. Illustrated fiction can be understood as a perfect blend of images and prose to tell a story. Various forms of this medium comprise of fiction written for adults or children, magazines, journals, comedy, and picture books. (Wikipedia)

First sketches of illustrated fiction can be seen from paintings of William Hogarth for Henry Fielding's famous novel Tom Jones, in order to exemplify the physical appearance of its characters. Other exemplars of illustrated editions in this period are Tobias Smollett's The Adventures of Peregrine Pickle, and Oliver Goldsmith's The Vicar of Wakefield. During this period, numerous factors catalyzed the increasing popularity of illustrated fiction. Mechanical developments that occurred in the western world during the end of the $18^{\text {th }}$ century helped the publishers to print pictures easily and cheaply. Illustrated classics, in comparison to their prose editions, were preferred by the readers, because illustrated fiction demanded less effort from the readers and was by far committed to memory. Many writers of this period, such as John Ruskin and Charles Dickens were heavily attracted towards the novelty, lucidity, and brevity of the illustrated fiction. 
The Pickwick Papers of Charles Dickens amplified the popularity of illustrated fiction in the $19^{\text {th }}$ century. Serialized illustrated editions of Dickens' works gained wide popularity and many writers and publishers of the century followed his path. There were versatile factors that caused for the wide popularity of illustrated editions. The publishers were more inclined towards the illustrated edition than the prose edition for the reasons of popularity among the readers and lack of commercial risks. The traditional unillustrated multi-volume works were less preferred by the readers and were time-consuming. Thus, the pictorial representations of illustrated editions attracted the readers. As a result, illustrated editions brought a large amount of advertising revenue and they became the main mode of advertisement. (Wikipedia)

Illustrated fiction has lost its popularity during the second half of the $19^{\text {th }}$ century due to the further developments that came into the panorama of technology. The emergence of film adaptations of literary works, television, photojournalism, unexpected hike in the labor charges, and decline of the publication of serials caused the diminishing popularity of illustrated fiction. Along with these facts, modern literary creations, such as the works of E.M. Foster, Virginia Woolf, and William Makepeace Thackeray did not suit for the illustrated version. Apart from these elements, illustrated fiction has lost its novelty and failed to magnetize the readers. Thus, the illustrated fiction faded away from the scene of an adult's fiction and constrained to children's fiction and comic serials. However, illustrations were still used in the cover pages to attract the readers and often came as the limited luxury edition. (Wikipedia)

Khaled Hosseini is one of the few writers in the $21^{\text {st }}$ century, who makes use of the wide scope of illustrated fiction. His work, Sea Prayer, which was inspired by the story of Alan Kurdi, a three-year-old Syrian refugee who was drowned in the Mediterranean sea while trying to run away from his troublesome homeland to Europe. This work is dedicated to the 
Syrian refugees, who suffer immensely in the period of intense war and violence. The Guardian first published this work online in 2017 and the hardcover edition was published in 2018, accompanied by the pictorial illustrations of the famous artist Dan Williams. The work is written in the form of a letter from a father to his son on their journey to find a safe shelter. The work can be divided into two distinctive parts. The first part consists of the retrospective narrations of the landscape and the life in pre-war Syria. The second part comprises of the poignant narrations of sufferings and persecutions during the times of war and violence, and the father's lament on the lost glory of their homeland and he mourns for the lost privileges of his son.

Reminiscence of Father's childhood memories in the farmhouse of his father, situated on the outskirts of the city of Homs, portray his nostalgic childhood experiences such as the natural scenery of the countryside and different aspects of various seasons. Along with these, the religious harmony that existed in pre-war Syria is also portrayed in the work, "a mosque for us Muslims, a church for our Christian neighbors, and a grand souk for us all to haggle over gold pendants and fresh produce and bridal dresses”.

"First came the protests. Then the siege". Hosseini's remark on the works brings the elements of war, violence, and the subsequent sufferings and refugee life. "The skies spitting bombs. Starvation. Burials". He bemoans over the traumas faced by themselves and their fellow beings. Then, addressing to his son, he continues narrating about the stark experiences during the period of war and weeps for the denied childhood luxuries of his son. Thus, the second part of the work displays the number of miseries and torments faced by the Syrians during the dark phase of the nation's history.

Thus, the work again vindicates Hosseini's concern over the sufferings of refugees, well-knit plot, narrative style, the abundance of images and symbols, and a call for peace and humanity. However, the unique charm of this work is the pictorial illustrations that move 
hand in hand with the prose during the narrative of this work. These illustrations lend a hand to the readers to comprehend the work with ease and often pass on the element of experience to the readers. Thus, the images that are illustrated in the work imprint the story into the minds of readers and convey the themes and messages of the work with more impact.

One of the foremost advantages of illustrated editions is that they help the readers to watch and experience the narrative course of the work as it is in a movie or stage performance. The modern age has witnessed drastic changes in every sphere of life. People are more inclined towards the use of digital modes of communication than the traditional methods. The illustrated fiction can become more effective than the conventional and popular prose fiction. Thus, the work Sea Prayer shows the importance of the revival of illustrated fiction into the world of adult's fiction and urges for the united efforts from humankind to bring peace and harmony in the world. 


\section{Works Cited}

Hosseini, Khaled. Sea Prayer. Illus. Dan Williams. Bloomsbury, 2018.

Illustrated Fiction. Wikipedia: The Free Encyclopedia. Wikimedia Foundation. 15 January 2019. < https://en.wikipedia.org/wiki/Illustrated_fiction> 